\title{
PENGARUH PEMBELAJARAN PROBLEM SOLVING MODEL POLYA TERHADAP KEMAMPUAN MEMECAHKAN MASALAH MATEMATIKA MAHASISWA
}

\author{
Indri Anugraheni \\ Universitas Kristen Satya Wacana
}

\begin{abstract}
Abstrak
Penelitian bertujuan untuk mengetahui adanya perbedaan yang signifikan antara kemampuan pemecahan masalah matematika mahasiswa pada kelompok yang menerapkan pembelajaran Problem Solving Model Polya dan kelompok yang menerapkan dengan menggunakan model konvensional. Desain yang digunakan dalam penelitian ini adalah Quasy Experimental Nonequivalent Control Group. Metode pengumpulan data pada penelitian ini adalah tes kemampuan pemecahan masalah matematika. Teknik analisis data dengan menggunakan uji t untuk mengukur dan mengetahui perbedaan kemampuan pemecahan masalah matematika mahasiswa pada kelompok eksperimen setelah diberi perlakuan. Hasil analisis data penelitian dengan menggunakan uji t diperoleh hasil t hitung < t tabel $(5,415>1,671)$ dan nilai signifikansi $<0,05$ $(0,000<0,05)$. Maka dari itu menunjukkan bahwa ada perbedaan yang signifikan pada kemampuan memecahkan masalah matematika mahasiswa antara kelompok yang menggunakan pembelajaran Problem Solving Model Polya dengan kelompok yang menggunakan model konvensional.
\end{abstract}

Kata Kunci: Pembelajaran Problem Solving, Model Polya, Kemampuan Pemecahan Masalah

\begin{abstract}
This study aims to determine the significant differences in the ability of problem solving of student's mathematics in groups that implement learning Problem Solving Polya Model and groups that apply the conventional model. The research design used is Quasy Experimental Nonequivalent Control Group. Data collection method used is math problem solving test. Data analysis technique use $t$ test to know the difference of problem solving ability of student in experimental group after given treatment. Result of data analysis by using $\mathrm{t}$ test obtained $\mathrm{t}$ count $<\mathrm{t}$ table $(5,415>1,671)$ and significance value $<0,05(0,000<0,05)$. Therefore, shows that there is a significant difference in the ability of solving the mathematical problems of students between groups using the Problem Solving Model Polya Model with groups using conventional models.
\end{abstract}

Keywords: Problem Solving Learning, Polya Model, Problem Solving Skill

\section{PENDAHULUAN}

Matematika merupakan bidang ilmu banyak digunakan dalam kehidupan sehari-hari. Dalam kehidupan sehari-hari tidak lepas dari permasalahan Matematika. Permasalahan Matematika berkaitan dengan pemecahan masalah Matematika. Pemecahan masalah merupakan hal yang penting untuk ditanamkan kepada mahasiswa/siswa karena banyak mahasiswa/siswa yang tidak dapat mengimplementasikan pemecahan masalah dalam kehidupan sehari-hari. Mata Kuliah pemecahan Matematika perlu diberikan kepada mahasiswa agar dapat membekali mahasiswa khususnya mahasiswa Pendidikan Guru Sekolah Dasar (PGSD) dengan menumbuhkan kemampuan berpikir logis, analitis, kritis, sistematis dan kreatif. Oleh karena itu mahasiswa diharapkan mampu menanamkan konsep atau prinsip matematika yang diaplikasikan dalam pemecahan masalah. Hal ini sejalan dengan Kurniasari, Dwijanto, Soedjoko (2014) bahawa Era globalisasi saat ini menuntut perkembangan dunia pendidikan untuk mampu membuat siswa/mahasiswa mengembangkan pengetahuan, ketrampilan, dan kreativitasnya dalam memperoleh, memilih, dan mengelola informasi.

Setiap mahasiswa/siswa tidak dapat menghindari kesulitan dalam belajar Matematika. Harus disadari bahwa mahasiswa/siswa mengalami tingkat kesulitan yang berbeda-beda sesuai kemampuan kognitif mereka dalam belajar Matematika. Mahasiswa/siswa cenderung menghindari permasalahan-permasalahan yang diangap sulit dalam Matematika. Mereka mencari permasalahan yang mudah diselesaikan sehingga tidak perlu memikirkan solusi dari permasalahan yang sulit. Oleh karena itu mahasiswa perlu menanamkan pemahaman bahwa Matematika itu sangat penting.

Pentingnya pemecahan masalah Matematika diperkuat dengan pernyataan Wilson dalam National Council of Teachers Mathematics (NCTM) bahwa "Problem solving has a special importance in study of mathematics. A primary goal of mathematics teaching and learning is develop the ability to solve a wide variety of complex mathematics problems" (Wilson, 1993: 57).

Sri Adi Widodo (2013) menyatakan bahwa Pemecahan masalah adalah suatu proses yang digunakan untuk menyelesaikan masalah. Masalah terjadi jika seseorang (siswa/mahasiswa) tidak mempunyai aturan yang dapat dipergunakan untuk mengatasi kesenjangan antara situasi saat ini dan tujuan yang akan dicapai. Kemampuan memecahkan suatu masalah adalah kemampuan kognitif yang berada pada tingkat tinggi. Sukmadinata dan As'ari (2005 : 24) menjelaskan bahwa tahap berpikir pada pemecahan masalah setelah tahap 
evaluasi yang menjadi bagian dari tahapan kognitif pada taksonomi Bloom.

Yeni Candra Vilianti, dkk (2018, 23) menyatakan bahwa Pemecahan masalah dalam masalah matematika membutuhkan sistematika dalam solusi penyelesaiannya. Memahami masalah soal matematika sangat diperlukan dalam pemecahan masalah, dengan pemahaman akan memudahkan siswa dalam memecahkan masalah matematik. Hal ini menunjukkan bahwa kemampuan memecahkan masalah adalah suatu kemampuan kognitif pada tingkat tinggi. Pemecahan masalah menjadi hal penting dalam kegiatan pembelajaran baik di sekolah dasar hingga perguruan tinggi. Berdasarkan beberapa pendapat maka disimpulkan bahwa pemecahan masalah adalah proses berpikir siswa/mahasiswa pada ranah kognitif tingkat tinggi dimana mahsiswa/siswa mampu menganalisis, mengevaluasi permasalahan yang diberikan dengan menggunakan pengalaman yang dimiliki sebelumnya.

Pembelajaran Matematika merupakan bagian dari pendidikan nasional. Pembelajaran Matematika memegang peran sangat penting bagi perkembangan ilmu pengetahuan dan teknologi. Pembelajaran Matematika berkaitan dengan masalah-masalah matematika yang berupa pertanyaan/soal yang berkaitan dengan kehidupan sehari-hari. Pembelajaran pemecahan masalah matematika dapat membantu siswa/mahasiswa dalam mengembangkan kemampuan memecahkan masalah, mengembangkan kemampuan berpikir dan mengembangkan kemampuan intelektualnya. Pada saat siswa/mahasiswa mampu memecahkan masalah, siswa/mahasiswa melakukan proses berpikir dalam pikiran sehingga siswa/mahasiswa mampu memperoleh jawaban dari masalah tersebut. Salah satu langkah pemecahan masalah yang dapat digunakan dalam menyelesaikan masalah matematika yaitu langkah pemecahan masalah model Polya dimana langkahlangkahnya dapat membantu siswa/mahasiswa dalam memandu dalam menemukan solusi dari suatu permasalahan yang diberikan.

Perubahan paradigma tentang pembelajaran Matematika diadaptasi dalam kurikulum di Indonesia dimulai dari Kurikulum 2004 (KBK) dan Kurikulum 2006. Salah satu tujuan pembelajaran Matematika di sekolah adalah "memecahkan masalah yang meliputi kemampuan memahami masalah, merancang model matematika, menyelesaikan model dan menafsirkan solusi yang diperoleh". (BSNP, 2006). Oleh sebab itu, pemecahan masalah menjadi fokus penting dalam perkembangan kurikulum matematika di sekolah mulai dari tingkat sekolah dasar sampai dengan perguruan tinggi. Jika kita cermati penguasaan siswa/mahasiswa pada setiap standar kompetensi dilengkapi dengan kompetensi dasar pemecahan masalah matematika dalam kehidupan sehari-hari. Kenyataan di lapangan banyak ditemukan siswa/mahasiswa mengalami kesulitan dalam memecakah masalah-masalah matematika dalam kehidupan sehari-hari.

Polya (1973) membagi empat langkah dalam memecahkan masalah matematika yang berkaitan dengan menyelesaikan soal pemecahan masalah tau soal cerita matematika, yaitu: 1) Memahami masalah (understanding problem). Pada tahap ini mahasiswa mampu memahami masalah yang diberikan oleh dosen yaitu mahasiswa mampu menentukan apa yang diketahui, apa yang ditanyakan dari soal pemecahan masalah yang diberikan oleh dosen. 2) Merencanakan pemecahan masalah (devising a plan). Tahap ini mahasiswa mampu menentukan dan membuat model matematika yang sesuai, menentukan strategi atau metode yang akan digunakan dari soal yang diberikan, melakukan pemisalan variabel. Mahasiswa mampu menuliskan langkah-langkah dalam menyelesaikan soal pemecahan masalah. 3) Melaksanakan rencana pemecahan masalah (carrying out the plan). Tahap ini mahasiswa melakukan rencana yang telah ditentukan pada tahap merencanakan pemecahan masalah. Pada tahap ini mahasiswa mampu memahami substansi materi dan keterampilan mahasiswa dalam melakukan perhitungan matematika pada soal pemecahan masalah. 4) Memeriksa kembali solusi yang diperoleh (looking back). Tahap ini mahasiswa melakukan refleksi dengan cara mengecek kembali, menguji kembali solusi yang telah ditentukan atau mencari alternative jawaban yang lain.

Krulik dan Rudnik (1995: 4) mengartikan bahawa pemecahan masalah adalah proses berpikir sebegai berikut: "Problem solving is the mean by wich an individual uses previously acquired knowledge, skill, and understanding to satisfy the demand of an unfamiliar situation". Dari pengertian tersebut mendefinisikan bahwa pemecahan masalah adalah usaha yang dilakukan individu (siswa/mahasiswa) menggunakan pengetahuan, keterampilannya dan pemahamannya untuk menemukan cara atau solusi dari suatu masalah yang ada. Sedangkan Ilhan Karatas \& Adnan Baki (2013) menjelaskan "Problem solving is recognized as an important life skill involving a range of processes including analyzing, interpreting, reasoning, predicting, evaluating and reflecting" yaitu pemecahan masalah merupakan keterampilan hidup yang penting karena melibatkan proses menganalisis permasalahan, menafsirkan, menalar, memprediksi, mengevaluasi dan merefleksikan.

Menurut Sari Kusuma Dewi, dkk alasan menggunakan pemecahan masalah model Polya, karena model Polya menyediakan kerangka kerja yang tersusun rapi untuk menyelesaikan masalah yang kompleks sehingga dapat membantu siswa dalam memecahkan masalah. Beberapa hasil penelitian yang telah dilakukan sebelumnya menunjukkan bahwa pemecahan model Polya efektif. Penelitian ini relevan dengan penelitian yang dilakukan Simpoll \& dkk (2017) bahwa pemecahan masalah adalah proses mencapai solusi yang dapat diterima untuk masalah baru, melibatkan pemikiran kritis dan kemampuan penalaran analitis.

Pemecahan masalah merupakan proses berpikir siswa/mahasiswa yang mampu menumbuhkan keterampilan memahami masalah, menganalisis masalah dengan menggunakan penafsiran dan penalaran untuk menyelesaikan masalah, serta mengevaluasi penyelesaian yang dikerjakan dan merefleksikannya.

Kondisi dilapangan menunjukkan bahwa banyak mahasiswa Pendidikan Guru Sekolah Dasar (PGSD) yang 
mengalami kesulitan dalam menyelesaikan masalah khsuusnya soal-soal pada mata kuliah Matematika. Hal ini dikarenakan siswa kurang memahami soal, kurang menggunakan penalaran maupun logika dalam menyelesaikan masalah. Sebagian mahasiswa keliru dalam menyelesaikan soal-soal. Hal ini dikarenakan mahasiswa masih kesulitan dalam menyelesaikan masalah matematika. Oleh karena itu peneliti mencoba membantu mahaiswa dalam menyelesaikan soal-soal pemecahan masalah dengan mengunakan pemecahan masalah model Polya.

\section{METODE}

Metode penelitian yang digunakan adalah penelitian eksperimen dengan menggunakan metode kuantitatif yaitu eksperimen semu (quasy experimental design) dengan menggunakan rancangan penelitian Nonequivalent Control Group Design.

Tabel 1. Rancangan Pretest-posttest Control Group

\begin{tabular}{ll}
\multicolumn{2}{c}{ Design } \\
\hline $\mathrm{O}_{1}$ & $\mathrm{X}$ \\
$\mathrm{O}_{2}$ & \\
\hline $\mathrm{O}_{3}$ & \\
$\mathrm{O}_{4}$ & \\
\hline
\end{tabular}

Gambar 1. Rancangan Penelitian

(Sumber : Sugiyono, 2012, 79)

Keterangan :

$\mathrm{O}_{1}$ : Pretest pada kelompok eksperimen

$\mathrm{O}_{2}$ : Posttest pada kelompok eksperimen

$\mathrm{O}_{3}$ : Pretest pada kelompok kontrol

$\mathrm{O}_{4} \quad$ : Posttest pada kelompok kontrol

$\mathrm{X}$ : Perlakuan model Pembelajaran Problem Solving Model Polya

Pretest diberikan pada kelompok eksperimen dan kelompok kontrol $\left(\mathrm{O}_{1}\right.$ dan $\left.\mathrm{O}_{3}\right)$ untuk menguji dan mengukur kemampuan awal pemecahan masalah mahasiswa. Setelah diberikan perlakuan maka kelompok eksperimen dan kelompok kontrol $\left(\mathrm{O}_{2}\right.$ dan $\left.\mathrm{O}_{4}\right)$ akan diberikan posttest yang sama untuk mengetahui perbedaan yang signifikan antara tes akhir pada kelompok eksperimen dan pada kelompok kontrol.

Populasi penelitian ini adalah mahasiswa calon guru SD mata kuliah stategi pemecahan masalah matematika. Penelitian yang dilakukan menggunakan simple random sampling karena pengambilan anggota sampel penelitian dari populasi dilakukan secara acak tanpa memperhatikan strata yang ada dalam populasi tersebut. Oleh karena itu sampel yang diambil dari populasi harus betul-betul sampel yang representatif. Sampel dalam penelitian ini adalah Mahasiswa kelas B sebagai kelompok eksperimen yang terdiri dari 30 mahasiswadan mahasiswa kelas $\mathrm{C}$ sebagai kelompok Kontrol yang terdiri dari 30 mahasiswa. Seluruh mahasiswa dalam kelompok yang menjadi sampel diberikan tes kemampuan pemecahan masalah Matematika. Kemudian data hasil penelitian semuanya dianalisis.
Penelitian ini terdiri dari dua variabel yaitu variabel bebas dan variabel terikat. Variabel bebas dalam penelitian ini adalah pembelajaran model Polya. Dan variabel terikat dalam penelitian ini adalah kemampuan memecahkan masalah matematika. Dengan demikian desain analisisnya yang digunakan adalah uji-t.

Teknik pengumpulan data dalam penelitian ini adalahh dengan tes. Tes digunakan untuk mengukur kemampuan memecahkan masalah matematika. Tes dilakukan sebanyak dua kali yaitu sebelum diberikan pembelajaran Problem Solving kepada mahasiswa (pretest) dan sesudah diberikan pembelajaran kepada mahasiswa (posttest). Pemberian tes awal (pretest) kepada mahasiswa bertujuan untuk mengukur kemampuan awal mahasiswa sebelum mendapatkan perlakuan pembelajaran Problem Solving Model Polya. Sedangkan pemberian tes akhir bertujuan untuk melihat kemampuan akhir yang dicapai mahasiswa sesudah diberikan perlakuan pembelajaran Problem Solving Model Polya. Sebelum tes digunakan, terlebih dahulu dilakukan di uji coba kemudian dilakukan analisisi instrumen yaitu uji validitas dan reliabilitas soal.

\section{HASIL DAN PEMBAHASAN}

Hasil penelitian kemampuan memecahkan masalah matematika dilakukan penilaian dari pretest dan posttest. Tes yang diberikan berupa soal tes kemampuan memecahkan masalah matematika sebanyak 10 soal. Tes digunakan pada dua kelompok sebagai subjek penelitian yaitu kelompok eksperiman dan kelompok kontrol. Berikut adalah rata-rata hasil nilai pretest dan posttest pada kelompok control dan kelompok eksperimen.

Tabel 2. Rata-Rata Nilai Pretest dan Posttest

\begin{tabular}{lcc}
\hline \multicolumn{2}{c}{ Rata-Rata } \\
\hline & Pretest & Posttest \\
\hline Kelas & 54,17 & 76,14 \\
Eksperimen & & \\
\hline Kelas Kontrol & 53,93 & 63,57 \\
\hline
\end{tabular}

Berdasarkan table 2 menunjukkan bahwa ratarata hasil nilai pretest dan hasil nilai posttest yang diperoleh pada kelompok kontrol maupun kelompok eksperimen pada tabel di atas menunjukkan bahawa adanya peningkatan antara kemampuan memecahkan masalah matematika dari nilai rata-rata hasil pretest dengan hasil posttest.

Sebelum peneliti melakukan uji hipotesis terlebih dahulu melakukan uji normalitas dan uji homogenitas. Uji normalitas dilakukan pada hasil tes kemampuan memecahkan masalah pretest dan hasil tes kemampuan memecahkan masalah posttest mahasiswa kelompok eksperimen dan kelompok kontrol. Normalitas data dapat dilihat dari hasil nilai signifikansinya. Jika nilai probabilitas atau signifikansi lebih dari 0,05 ( $p>0,05)$ maka dapat dikatakan bahwa data berdistribusi normal, dan nilai probabilitas atau signifikansi lebih dari $0,05(\mathrm{p}<0,05)$ maka dapat dikatakan bahwa data tidak berdistribusi normal. 
Uji normalitas dalam penelitian ini digunakan program SPSS 22. Uji normalitas dilakukan untuk mengukur normalitas pada data nilai pretest dan nilai posttest pada kelompok eksperimen dan kelompok kontrol. Hasil analisis uji normalitas Pretest dan Postest disajikan dalam tabel sebagai berikut.

Tabel 3. Uji Normalitas data Pretest One-Sample Kolmogorov-Smirnov Test

\begin{tabular}{ccrr}
\hline & & PreEks & \multicolumn{1}{c}{ PreKon } \\
\hline \multirow{2}{*}{ Normal } & & 30 & 30 \\
Parameters $^{\mathrm{a}}$ & Mean & 54.3167 & 54.6333 \\
& Std. & 9.32967 & $1.00558 \mathrm{E} 1$ \\
& Deviation & & \\
Most Extreme & Absolute & .128 & .124 \\
Differences & Positive & .128 & .113 \\
& Negative & -.084 & -.124 \\
Kolmogorov-Smirnov Z & .703 & .679 \\
Asymp. Sig. (2-tailed) & .706 & .746 \\
\hline
\end{tabular}

Berdasarkan tabel 2 di atas menunjukkan bahwa kelompok eksperimen nilai Kolmogorov-Smirnov Z sebesar 0,703 dengan Asymp Sig 0,706. Oleh karena Asymp Sig $=0,706>0,05$ maka dapat disimpulkan bahwa data nilai pretest kelompok eksperimen berdistribusi normal. Kelompok Kontrol nilai Kolmogorov-Smirnov Z sebesar 0,679 dengan Asymp Sig 0,746. Oleh karena Asymp Sig $=0,746>0$ maka dapat disimpulkan bahwa data nilai pretest kelompok kontrol berdistribusi normal.

Tabel 4. Uji Normalitas data Postest One-Sample Kolmogorov-Smirnov Test

\begin{tabular}{ccrr}
\hline & & PostEks & PostKon \\
\hline \multirow{2}{*}{ Normal } & $\mathrm{N}$ & 30 & 30 \\
Parameters $^{\mathrm{a}}$ & Mean & 76.20 & 63.81 \\
& Std. Deviation & 9.365 & 8.334 \\
Most Extreme & Absolute & .157 & .176 \\
Differences & Positive & .157 & .108 \\
& Negative & -.091 & -.176 \\
Kolmogorov-Smirnov Z & .861 & .963 \\
Asymp. Sig. (2-tailed) & .448 & .312 \\
\hline
\end{tabular}

Berdasarkan tabel 2 di atas menunjukkan bahwa kelompok eksperimen nilai Kolmogorov-Smirnov Z sebesar 0,861 dengan Asymp Sig 0,448. Oleh karena Asymp Sig $=0,448>0,05$ maka dapat disimpulkan bahwa data nilai pretest kelompok eksperimen berdistribusi normal. Kelompok Kontrol nilai Kolmogorov-Smirnov Z sebesar 0,963 dengan Asymp Sig 0,312. Oleh karena Asymp Sig $=0,312>0$ maka dapat disimpulkan bahwa data nilai pretest kelompok kontrol berdistribusi normal.
Tabel 5. Uji Homogenitas data Pretest Test of Homogeneity of Variance ${ }^{\text {a }}$

\begin{tabular}{cccccc}
\hline & & $\begin{array}{c}\text { Levene } \\
\text { Statistic }\end{array}$ & df1 & df2 & Sig. \\
\hline $\begin{array}{c}\text { Hasil } \\
\text { Belajar }\end{array}$ & Based on Mean & .338 & 1 & 58 & .563 \\
& $\begin{array}{c}\text { Based on } \\
\text { Median }\end{array}$ & .307 & 1 & 58 & .581 \\
& $\begin{array}{c}\text { Based on } \\
\text { Median and with } \\
\text { adjusted df }\end{array}$ & .307 & 1 & 57.9 & .581 \\
& $\begin{array}{c}\text { Based on } \\
\text { trimmed mean }\end{array}$ & .335 & 1 & 58 & .565 \\
\hline
\end{tabular}

Tabel 5. Uji Homogenitas data Postest Test of Homogeneity of Variance ${ }^{a}$

\begin{tabular}{|c|c|c|c|c|c|}
\hline & & $\begin{array}{l}\text { Levene } \\
\text { Statistic }\end{array}$ & df1 & df 2 & Sig. \\
\hline \multirow{4}{*}{$\begin{array}{l}\text { Hasil } \\
\text { Belajar }\end{array}$} & Based on Mean & .245 & 1 & 58 & .622 \\
\hline & $\begin{array}{l}\text { Based on } \\
\text { Median }\end{array}$ & .369 & 1 & 58 & .546 \\
\hline & $\begin{array}{c}\text { Based on } \\
\text { Median and with } \\
\text { adjusted df }\end{array}$ & .369 & 1 & $\begin{array}{r}57.8 \\
01\end{array}$ & .546 \\
\hline & $\begin{array}{c}\text { Based on } \\
\text { trimmed mean }\end{array}$ & .290 & 1 & 58 & .592 \\
\hline
\end{tabular}

Berdasarkan hasil uji Homogenitas pada tabel 4 di atas untuk kesamaan ragam (variansi) di atas diperoleh taraf signifikansi 0,563 pada nilai pretest. Karena nilai Sig $=0,563>0,05$ maka dapat disimpulkan bahwa kedua kelompok data mempunyai varian sama atau homogen. Sedangkan pada tabel 5 di atas menunjukkan bahwa nilai posttest diperoleh signifikansi sebesar 0,622. Karena nilai Sig $=0,622>0,05$ maka dapat disimpulkan bahwa kedua kelompok data mempunyai varian sama atau homogen. Oleh karena itu dapat disimpulkan bahwa kemampuan pemecahan masalah matematika mahasiswa pada soal pretest dan kemampuan pemecahan masalah pada soal posttest pada kelompok eksperimen dan kelompok kontrol mempunyai kemampuan (variasi) yang identik (homogen).

Hasil uji normalitas dan homogenitas menunjukkan bahwa kedua sampel kelompok eksperimen dan kelompok kontrol berdistribusi normal dan mempunyai variansi yang sama. Selanjutnya dilakukan uji hipotesis dengan cara menggunakan teknik uji t-test dengan rumus Independent Samples Test dengan mengolah menggunakan program SPSS 22. Hasil uji t-tes sebaran data disajikan dalam tabel berikut ini:

Tabel 6. Hasil Statistik Rata-rata Kemampuan Memecahkan Masalah Group Statistics 


\begin{tabular}{lccrrr}
\hline & kelas & N & \multicolumn{1}{c}{ Mean } & $\begin{array}{c}\text { Std. } \\
\text { Deviation }\end{array}$ & $\begin{array}{c}\text { Std. Error } \\
\text { Mean }\end{array}$ \\
\hline IPK & Eks & 30 & 76.20 & 9.365 & 1.710 \\
& Kontrol & 30 & 63.81 & 8.334 & 1.522 \\
\hline
\end{tabular}

Dari tabel 6 menunjukkan ada perbedaan rata-rata kemampuan memecahkan masalah skor antara kelompok eksperimen dan kelompok kontrol. Namun demikian, apakah perbedaan kedua kelompok tersebut signifikan pada 0,05 maka diperlukan uji dengan menggunakan uji beda rata-rata antara dua sampel yang independen seperti ditampilkan pada tabel 7 berikut:

Tabel 7. Uji-t

Independent Samples Test

\begin{tabular}{|c|c|c|c|c|c|c|c|c|}
\hline & $\begin{array}{r}\text { Leve } \\
\text { Test } \\
\text { Equal } \\
\text { Varia }\end{array}$ & $\begin{array}{l}\text { ne's } \\
\text { for } \\
\text { ity of } \\
\text { nces }\end{array}$ & & \multicolumn{5}{|c|}{ t-test for Equality of Means } \\
\hline & \multirow[b]{2}{*}{$\mathrm{F}$} & \multirow[b]{2}{*}{ Sig. } & \multirow[b]{2}{*}{$\mathrm{t}$} & \multirow[b]{2}{*}{$\mathrm{df}$} & \multirow{2}{*}{$\begin{array}{l}\text { Sig. } \\
(2- \\
\text { taile } \\
\text { d) }\end{array}$} & \multirow{2}{*}{$\begin{array}{c}\text { Mea } \\
\mathrm{n} \\
\text { Diffe } \\
\text { rence }\end{array}$} & \multirow{2}{*}{$\begin{array}{l}\text { Std. } \\
\text { Error } \\
\text { Differ } \\
\text { ence }\end{array}$} & $\begin{array}{c}95 \% \\
\text { Confide } \\
\text { nce } \\
\text { Interval } \\
\text { of the } \\
\text { Differen } \\
\text { ce } \\
\end{array}$ \\
\hline & & & & & & & & $\begin{array}{cc}\text { Lo } & \text { Up } \\
\text { wer } & \text { per }\end{array}$ \\
\hline $\begin{array}{cc}\mathrm{I} & \text { Equal } \\
\mathrm{P} & \text { varianc } \\
\mathrm{K} & \mathrm{es} \\
& \text { assume } \\
& \mathrm{d}\end{array}$ & .245 & .622 & $\begin{array}{r}5.4 \\
15\end{array}$ & 58 & .000 & $\begin{array}{r}12.3 \\
93\end{array}$ & 2.289 & $\begin{array}{rr}7.8 & 6.97 \\
12 & 5\end{array}$ \\
\hline $\begin{array}{l}\text { Equal } \\
\text { varianc } \\
\text { es not } \\
\text { assume } \\
\quad d\end{array}$ & & & .415 & $\begin{array}{r}57.2 \\
30\end{array}$ & .000 & $\begin{array}{r}12.3 \\
93\end{array}$ & 2.289 & $\begin{array}{rr}7.8 & 16 . \\
10 & 976\end{array}$ \\
\hline
\end{tabular}

Hasil uji t ditemukan nilai $\mathrm{t}$ hitung $>\mathrm{t}$ tabel yaitu $5,415>1,67065$ dengan sig (2-tailed) 0,000. Oleh karena nilai sig $<0,05$ maka dapat disimpulkan bahwa ada perbedaan yang signifikan antara rata-rata kemampuan memecahkan masalah matematika pada kelompok Eksperimen dan kelompok kontrol. Oleh karena nilai ratarata kemampuan pemecahan masalah matematika kelompok eksperimen lebih tinggi dibandingkan nlai ratarata kelompok kontrol maka dapat disimpulkan bahwa kemampuan mahasiswa yang menggunakan pembelajaran problem solving model Polya lebih baik daripada pembelajaran konvensional.

\section{PENUTUP}

\section{Simpulan}

Berdasarkan hasil penelitian yang dijelaskan di atas, maka dapat ditarik kesimpulan bahwa terdapat perbedaan yang signifikan antara kelompok kemampuan memecahkan masalah matematika dengan menggunakan pembelajaran Problem Solving model Polya antara kelompok yang menerapkan model pembelajaran konvensional. Hal tersebut dapat dilihat dari hasil nilai pemecahan masalah matematika posttest pada kelompok kontrol lebih rendah dibandingkan kelompok eksperimen.

Jadi, pembelajaran pemecahan masalah matematika dengan model Polya mampu meningkatkan kemampuan memecahkan masalah matematika mahasiswa PGSD. Mahasiswa mampu memahami permasalahnyang diberikan, mahasiswa mampu melaksanakan penyelesaian, mahasiswa mampu menyelesaikan masalah dan mahasiswa mampu mengecek kembali hasil penyelesaiannya. Hal ini relevan dengan penelitian yang dilakukan Muhamad Aris \& Zaenuri (2018) bahwa kualitas pembelajaran siswa terdiri dari tiga tahap yaitu tahap perencanaan, tahap implementasi, dan tahap evaluasi.

\section{Saran}

Berdasarkan simpulan di atas maka dapat disarankan bagi pendidik khususnya dosen/guru untuk menggunakan pembelajaran Problem Solving Model Polya yang mampu meningkatkan kemampuan memecahkan masalah matematika. Agar kemampuan memecahkan masalah matematika siswa/mahasiswa meningkat maka dalam kegiatan pembelajaran perlunya mengaitkan pembelajaran dengan kehidupan sehari-hari, membiasakan siswa/mahasiswa untuk mampu menyelesaikan masalahmasalah yang diberikan. Selain itu dalam menyelesaikan masalah matematika diharapkan siswa mampu memahami masalah, merencanakan penyelesaian, melakasanakan penyelesaian serta memeriksa dan menarik kesimpulan dari permasalahan tersebut. Mengingat pentingnya kemampuan memecahkan masalah baik dalam lingkup sekolah dasar hingga perguruan tinggi, maka diharapkan peneliti selanjutnya mampu menciptakan pembelajaran yang lebih inovatif sehingga hasil yang diharapkan lebih maksimal dari penelitian sebelumnya.

\section{DAFTAR PUSTAKA}

Dewi, S.K., Suarjana, Sumantri. (2014). Penerapan Model Polya untuk Meningkatkan Hasil Belajar dalam Memecahkan Soal Cerita Matematika Siswa Kelas V. Jurnal Mimbar PGSD, 2(2).

Ejin, S. (2016). Pengaruh Model Problem Based Learning (PBL Terhadap Pemahaman Konsep dan Keterampilan Berpikir Kritis Siswa Kelas IV SDN Jambu Hilir Baluti 2 Pada Mata Pelajaran Ilmu Pengetahuan Alam. Jurnal Pendidikan (Teori dan Praktik), 1(1), 66-72.

Kurniasari, Dwijanto, Soedjoko (2014). Keefektifan Model Pembelajaran MMP denganlangkah Pemecahan Masala Polya terhadap Kemampuan Berpikir Kreatif Siswa kelas-vii. Unnes Journal of Mathematics Education http://journal.unnes.ac.id/sju/index.php/ujme. $145-150$ 
Krulik, Stephen dan Rudnick, Jesse A. (1995). The New Sourcebook for Teaching Reasoning and Problem Solving in Elementary School. Boston : Temple University.

Karatas, I., \& Baki, A. (2013). The effect of learning environments based on problem solving on students' achievements of problem solving. International Electronic Journal of Elementary Education, 5(3), 249.Lidinillah, D. A. M. (2011). Heuristik dalam Pemecahan Masalah Matematika dan Pembelajarannya di Sekolah Dasar. Jurnal Elektronik. Universitas Pendidikan Indonesia.

Polya, G. 1973. How To Solve it: A New Aspect of Mathematical Method. New Jersey, USA: Pricenton University Press

Rahmadani, N., \& Anugraheni, I. (2017). PENINGKATAN AKTIVITAS BELAJAR MATEMATIKA MELALUI PENDEKATAN PROBLEM BASED LEARNING BAGI SISWA KELAS 4 SD. Scholaria: Jurnal Pendidikan Dan Kebudayaan, 7(3), 241-250.

Sari Kusuma Dewi, Suarjana, Md. Sumantri. J. (2014). Penerapan Model Polya untuk Meningkatkan Hasil Belajar dalam Memecahkan Soal Cerita Matematika Siswa kelas V. Jurnal Mimbar PGSD Universitas Pendidikan Ganesha Jurusan PGSD., 2(1). Sugiyono. (2012). Metode Penelitian Kuantitatif Kualitatif dan $R \& D$. Bandung: Alfabeta.

Simpol, N. S. H., Shahrill, M., Li, H. C., \& Prahmana, R. C. I. (2017, December). Implementing thinking aloud pair and Pólya problem solving strategies in fractions. In Journal of Physics: Conference Series (Vol. 943, No. 1, p. 012013). IOP Publishing.Sri Adi Widodo. ANALISIS KESALAHAN DALAM PEMECAHAN MASALAH Jurnal Pendidikan dan Pengajaran, Jilid 46, Nomor 2, Juli 2013, hlm.106-113108

Sunandar, M. A., Zaenuri, Z., \& Dwidayati, N. K. (2018). Mathematical Mathematical Problem Solving Ability Of Vocational School Students On Problem Based Learning Model Nuanced Ethnomatematics Reviewed From Adversity Quotient. Unnes Journal of Mathematics Education Research, 7(1), 1-8.

Vilianti, Y. C., Pratama, F. W., \& Mampouw, H. L. (2017). Description of The Ability of Social Arithedical Stories by Study Problems by Students VIII SMP Reviewed from The Polya Stage. International Journal of Active Learning, 3(1), 23-32.

Wilson. 1993. Mathematical Problem Solving. New York: Macmilan Publishing Company. 